\title{
Surfactant Protein D and C-Reactive Protein as serum biomarkers in Chronic Obstructive Pulmonary Disease
}

\author{
Samia Mostafa *, Eman Obaia* Ghada Mahmoud Abd El Aziz \\ Marwa Fathi ${ }^{*}$ and Nabila laz** \\ Medical Biochemistry *, and Chest Departments** \\ Cairo and Beni Sweif University
}

\begin{abstract}
Introduction: With the growing awareness of COPD as a systemic disease, there has been a shift in the focus of biomarker discovery away from lung sources and toward blood specimens. Aim of Work: The aim of the present work was to evaluate the utility of serum SP-D compared to serum CRP as biomarkers in tracking disease progression of COPD and to assess the effect of smoking and inhaled steroid on their levels. Subjects and Methods: Seventy subjects were enrolled in this study divided into 2 main groups: healthy control group (30 subjects) and COPD patients' group (40 subjects).Serum SP-D and serum CRP were measured using enzyme linked immunsorpent assay method (ELISA). Results: revealed that COPD is associated with significant higher levels of both serum SP-D and CRP, while smoking is associated with significant higher levels of SP-D only. On the other hand, inhaled steroid is associated with significant lower serum levels of both SP-D and CRP. In addition, serum SP-D levels correlate positively with the severity of COPD disease while CRP levels showed no significant correlation with severity of the disease. Conclusion: These results empower the sensitivity of both markers in diagnosis of COPD and in following the response of the patients to steroid therapy. On the other hand, results suggest that $S P-D$ is more accurate than CRP as serum biomarker in tracking disease progression of COPD patients.
\end{abstract}

Key Words: COPD, Surfactant protein D, C reactive protein, Biomarker, Inhaled Steroid, Smoking.

\section{INTRODUCTION}

COPD is characterized by airflow limitation, chronic lung inflammation, and extrapulmonary systemic effects. In chronic lung inflammation, elevated protease and oxidant levels are believed to contribute to degradation of lung tissue and progression of COPD. When evaluating therapies for COPD or defining different patterns of the disease, markers that could provide insights into these destructive inflammatory processes would therefore be helpful. New biomarkers for COPD are being explored, including those in exhaled breath, induced sputum, bronchoalveolar lavage fluid, lung biopsy, and serum $^{(1,2)}$. A biomarker is defined as a biological marker that is objectively measured and evaluated as an indicator of normal biological, 
pathogenic processes, or pharmacologic responses to a therapeutic intervention ${ }^{(3)}$. Biomarkers can be genetic polymorphisms that contribute new pathogenic insights into $\mathrm{COPD}^{(4)}$ or parameters that may be used for the assessment of disease severity or effects of therapy. Compared with markers measured in other sample material, biomarkers determined in serum are reliably measured using equipment that is cost effective and readily available in clinical settings. However, these markers may be modulated by morbidities other than COPD and thus may, in some circumstances, represent epiphenomena unrelated to the COPD phenotype $^{(4)}$.

Surfactant protein (SP)-D is a biomarker for COPD. This marker is relatively specific for the lungs and can be measured in serum ${ }^{(5)}$. SP-D synthesis is mainly restricted to pulmonary tissues. Since SP-D is elevated in the circulation in response to lung pathology ${ }^{(6)}$, this protein could provide a useful marker of COPD ${ }^{(5)}$.

C-reactive protein (CRP) is one of the acute phase proteins that increase during systemic inflammation. It is one of the inflammatory markers that increases in COPD patients and relates to the pulmonary function ${ }^{(7)}$. It has been associated with an increased risk of incident myocardial infarction, stroke, unstable angina, and sudden coronary death $^{(7)}$. It contributes to the recruitment of circulating leucocytes, the uptake of low density lipoprotein cholesterol by macrophages, and ultimately to a destabilisation of vascular wall atheroma ${ }^{(8)}$.
The present study aimed to evaluate the utility of, surfactant protein D (SP-D) and CRP as serum biomarkers in COPD and to assess the effect of inhaled corticosteroids and smoking on levels of these biomarkers in COPD.

\section{SUBJECTS \& METHODS}

The present study was carried out at the outpatient clinic of Chest department at Beni Sueif University hospital during the period between (2009-2010).It included 70 subjects whom were divided into two groups as follows:

Group 1: included 40 patients suffering from varying degree of COPD. Spirometric criteria included FEV1 of less than $80 \%$ of predicted with an FEV1 to FVC ratio of less than $\quad 0.70 \quad$ (post-bronchodilator values). Their age varied from 4565.This group was further classified according to their smoking status and the treatment they receive into:

Group 1a: current-smokers and receiving inhaled steroid (ICS) (fluticasone for at least 2 years) (10 patients).

Group 1 b: ex-smokers and receiving inhaled steroid( fluticasone for at least 2 years ) (10 patients).

Group 1c: current smokers and not on inhaled steroid (10 patients).

Group 1d: ex-smokers and and not on inhaled steroid (10 patients).

Group 2: included 30 asymptomatic healthy control volunteers who matched with age and sex and were divided according to their smoking status into:

Group 2 a: 10 healthy current smokers. 
Group 2 b: 10 healthy ex- smokers. Group 2 c: 10 healthy non smokers.

Both groups 1 and 2 were subjected to: A detailed medical, tobacco and medication history taking, Physical examination, Chest $\mathrm{X}$ ray, Pulmonary function test( Spirometry before and after bronchodilator) and estimation of serum surfactant protein D and serum CRP .

Estimation of SP-D and CRP in serum by ELISA method.

Peripheral venous blood samples were collected from the patients and healthy subjects at the time of registration for the study The samples were collected in plain tubes and were allowed to clot for at least 30 minutes. They were then centrifuged at $1500 \times$ $g$ for 15 minutes at room temperature, divided into aliquots using a sterile plastic transfer pipette and frozen in $80^{\circ} \mathrm{C}$ conditions until use. The samples were thawed once and SP-D and CRP (Biovendor, Modrice, Czech Republic), were determined using commercially available ELISA kits.
Exclusion criteria: included a history of asthma or alpha-1 antitrypsin deficiency, other chest diseases, infection in the 3 weeks prior to screening, prior lung resection, and ischemic heart disease.

Statistical method:

The data was coded and entered using the statistical package SPSS version 15.The data was summarized using descriptive statistics: mean, standard deviation, minimal and maximum values for quantitative variables. Statistical differences between groups were tested using Independent sample $t$ test and ANOVA (analysis of variance) for quantitative normally distributed variables and Nonparametric Mann Whitney test and Kruskal Wallis test for not normally distributed quantitative variables. Correlations were done to test for linear relations between variables. Linear regression analysis was done to test for significant predictors for surfactant protein in serum. P-values less than or equal to 0.05 were considered statistically significant.

\section{RESULTS}

Table (1) Demographic Data of the studied population

\begin{tabular}{|l|l|l|l|l|l|l|l|l|}
\hline GROUPS & $\mathbf{N}$ & $\begin{array}{l}\text { Age } \\
\text { (Mean } \\
\mathbf{\text { SDD }}\end{array}$ & $\mathbf{S e x}$ & $\begin{array}{l}\text { Smoking } \\
\text { status }\end{array}$ & $\begin{array}{l}\text { ICS } \\
\text { Use }\end{array}$ & FEV1/FVC & FVC & FEV1 \\
\hline Group1a & 10 & $55(5)$ & $\mathrm{M}$ & Current & positive & $51.8 \pm 9.3$ & $83.9 \pm 16.3$ & $53.7 \pm 3$ \\
\hline Group 1b & 10 & $62(8)$ & $\mathrm{M}$ & Ex-Smokers & positive & $60.1 \pm 8.1$ & $91 \pm 8.6$ & $69.3 \pm 9.2$ \\
\hline Group 1c & 10 & $56(8)$ & $\mathrm{M}$ & Current & None & $45.7 \pm 17.7$ & $58 \pm 15.8$ & $29 \pm 4.3$ \\
\hline Group 1d & 10 & $69(6)$ & $\mathrm{M}$ & Ex-Smokers & None & $48.9 \pm 12.8$ & $68.7 \pm 15.9$ & $40.6 \pm 3$ \\
\hline Group 2a & 10 & $56(9)$ & $\mathrm{M}$ & Current & None & $83.56 \pm 8.2$ & $91.21 \pm 10.21$ & $88.2 \pm 10.5$ \\
\hline Group 2b & 10 & $63(5)$ & $\mathrm{M}$ & Ex-Smokers & None & $93.5 \pm 10.5$ & $96.3+8.56$ & $89.9 \pm 10.5$ \\
\hline Group 3c & 10 & $68(6)$ & $\mathrm{M}$ & None & None & $93.8 \pm 6.9$ & $96.6 \pm 7.3$ & $92.4 \pm 8.6$ \\
\hline
\end{tabular}


Table (2): Statistical analysis of serum SP-D levels $(\mathrm{ng} / \mathrm{ml})$ and serum plasma CRP(mg/dl) among COPD patients compared to control

\begin{tabular}{|l|l|l|l|l|l|l|l|}
\hline & \multicolumn{3}{|l|}{ SP-D in serum(ng/ml) } & \multicolumn{2}{l|}{ CRP in serum(mg/dl) } & \multirow{2}{*}{ P-value } \\
\cline { 2 - 7 } & $\mathbf{N}$ & Mean & S.D & P-value & Mean & S.D & \\
\hline Control & 30 & 58.3 & 31.63 & $<0.001$ & 2.7 & 1.03 & $<0.001$ \\
Patients & 40 & 319.03 & 206.29 & & 5.03 & 1.51 & \\
\hline
\end{tabular}

This table shows that there is a statistically significant difference between COPD patients and control subjects concerning both SP-D level in serum and serum CRP where COPD patients showed significantly higher values of SP-D and CRP when compared to control.

Table (3): Statistical analysis of serum SP-D (ng/ml) and CRP (mg/dl) levels among subjects of the Control group.

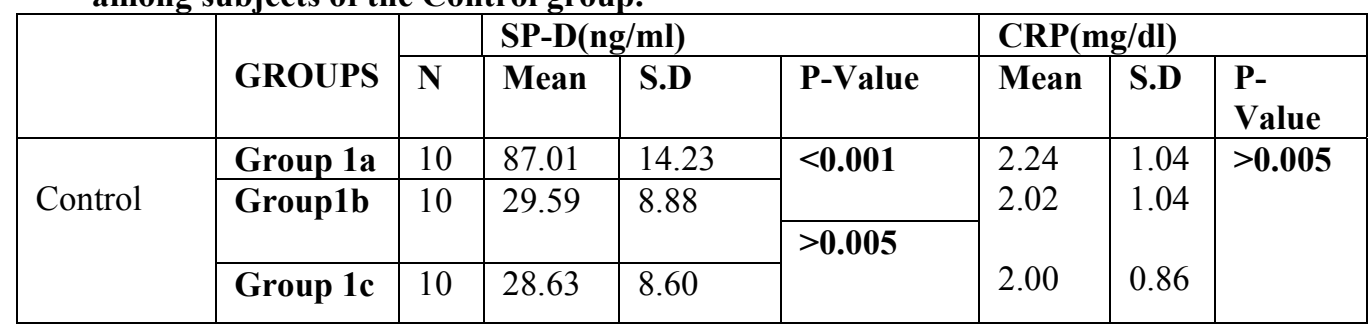

As regards serum levels of SP-D, this table shows that there is a statistically significant difference between current smokers control subjects (1a) and ex-smokers control subjects (1b) where a higher value was noticed with current smokers, while no statistical significant difference was found between ex-smokers control subjects (1b) and non smokers control subjects (1c).Concerning CRP serum levels, no statistically significant difference was found between these groups.

Table (4): Comparison of serum levels of SP-D (ng/ml) and serum CRP (mg/dl) between current smokers COPD patients and current smokers control subjects, and between ex-smokers COPD patients and ex-smokers control subjects.

\begin{tabular}{|c|c|c|c|c|c|c|c|c|c|}
\hline GROUPS & $\mathbf{N}$ & \multirow{3}{*}{$\begin{array}{l}\text { a } \\
\text { a' } \\
\text { n }\end{array}$} & Mean & S.D & P-value & \multirow{6}{*}{$\frac{a}{u}$} & Mean & S.D & P-value \\
\hline $\begin{array}{l}\text { Current smokers } \\
\text { COPD patients }\end{array}$ & 20 & & 439.6 & 316.7 & \multirow[b]{2}{*}{$<0.001$} & & 5.07 & 0.72 & \multirow[b]{2}{*}{$<0.001$} \\
\hline $\begin{array}{l}\text { Current smokers } \\
\text { control subjects }\end{array}$ & 10 & & 87.01 & 14.23 & & & 2.24 & 1.04 & \\
\hline $\begin{array}{l}\text { Ex smokers } \\
\text { COPD patients }\end{array}$ & 20 & & 198.49 & 81.4 & \multirow{3}{*}{$<0.001$} & & 5.00 & 1.52 & \multirow[b]{3}{*}{$<0.001$} \\
\hline \multirow{2}{*}{$\begin{array}{l}\text { Ex smokers } \\
\text { control subjects }\end{array}$} & \multirow[t]{2}{*}{10} & & 29.59 & 8.88 & & & 2.02 & \multirow[t]{2}{*}{1.04} & \\
\hline & & & & & & & & & \\
\hline
\end{tabular}


This table shows that serum levels of both SP-D and CRP were significantly higher among current smokers COPD patients compared to current smokers control and both SP-D and CRP were significantly higher among ex smokers COPD patients compared to ex smokers control.

Table (5): Comparison of serum levels of SP-D (ng/ml) and CRP between current smokers COPD patients and ex-smokers COPD patients.

\begin{tabular}{|c|c|c|c|c|c|c|c|c|c|}
\hline GROUPS & $\mathbf{N}$ & \multirow{3}{*}{$\frac{9}{a}$} & Mean & S.D & P-value & \multirow{3}{*}{$\hat{\imath}$} & Mean & S.D & P-value \\
\hline $\begin{array}{l}\text { Current } \\
\text { smokers COPD } \\
\text { patients }\end{array}$ & 10 & & 439.6 & 316.7 & $<0.001$ & & 5.07 & 0.72 & \multirow{2}{*}{0.089} \\
\hline $\begin{array}{ll}\text { Ex } & \text { smokers } \\
\text { COPD patients }\end{array}$ & 10 & & 198.49 & 81.4 & & & 5.00 & 1.52 & \\
\hline
\end{tabular}

This table shows that serum levels of SP-D was significantly higher among current smokers COPD patients compared to ex smokers COPD patients, while serum levels of CRP was insignificantly higher among current smokers COPD patients compared to ex smokers COPD patients.

Table (6): Statistical analysis of serum levels of SP-D (ng/ml) and CRP between current smokers COPD patients not on inhaled steroid and ex-smokers COPD patients not on inhaled steroid.

\begin{tabular}{|c|c|c|c|c|c|c|c|c|c|}
\hline GROUPS & $\mathbf{N}$ & \multirow{3}{*}{$\frac{\hat{a}}{\tilde{n}}$} & Mean & S.D & P-value & \multirow{3}{*}{$\hat{\underline{u}}$} & Mean & S.D & P-value \\
\hline $\begin{array}{l}\text { Current smokers } \\
\text { COPD patients } \\
\text { not on inhaled } \\
\text { steroid }\end{array}$ & 10 & & 663.56 & 19.17 & \multirow[t]{2}{*}{$<0.001$} & & 5.00 & 0.84 & \multirow[t]{2}{*}{0.008} \\
\hline $\begin{array}{l}\text { Ex smokers } \\
\text { COPD patients } \\
\text { not on inhaled } \\
\text { steroid }\end{array}$ & 10 & & 256.08 & 14.55 & & & 4.92 & 1.02 & \\
\hline
\end{tabular}

This table shows that serum levels of SP-D was significantly higher among current smokers COPD patients not on inhaled steroid(ICS)compared to ex smokers COPD patients not on ICS, while serum levels of CRP was insignificantly higher among current smokers COPD patients not on inhaled steroid compared to ex smokers COPD patients not on ICS. 
Table (7): Statistical analysis of serum levels of SP-D (ng/ml) and CRP between current smokers COPD patients on inhaled steroid (ICS) and current smokers COPD patients not on inhaled steroid.

\begin{tabular}{|c|c|c|c|c|c|c|c|c|c|}
\hline GROUPS & $\mathbf{N}$ & \multirow{3}{*}{$\frac{a}{a}$} & Mean & S.D & P-value & \multirow{3}{*}{$\hat{\underline{u}}$} & Mean & S.D & P-value \\
\hline $\begin{array}{l}\text { Current smokers } \\
\text { COPD patients } \\
\text { on ICS }\end{array}$ & 10 & & 215.60 & 13.80 & \multirow[t]{2}{*}{$<0.001$} & & 3.1 & 0.02 & \multirow{2}{*}{$<0.001$} \\
\hline $\begin{array}{l}\text { Current smokers } \\
\text { COPD patients } \\
\text { not on ICS }\end{array}$ & 10 & & 663.56 & 19.17 & & & 5.00 & 0.84 & \\
\hline
\end{tabular}

This table shows that serum levels of both SP-D and CRP were significantly lower among current smokers COPD patients on ICS compared to current smokers COPD patients not on ICS .

Table (8): Statistical analysis of serum levels of SP-D (ng/ml) and CRP between ex smokers COPD patients on inhaled steroids and ex-smokers COPD patients not on inhaled steroids

\begin{tabular}{|c|c|c|c|c|c|c|c|c|c|}
\hline GROUPS & $\mathbf{N}$ & \multirow{3}{*}{$\frac{\hat{1}}{\tilde{n}}$} & Mean & S.D & P-value & \multirow{3}{*}{$\hat{\sigma}$} & Mean & S.D & $\begin{array}{l}\text { P- } \\
\text { value }\end{array}$ \\
\hline $\begin{array}{l}\text { Ex- smokers } \\
\text { COPD patients } \\
\text { on ICS }\end{array}$ & 10 & & 140.91 & 14.97 & \multirow[t]{2}{*}{$<0.001$} & & 2.7 & 0.84 & \multirow[b]{2}{*}{$\begin{array}{l}<0 \\
001\end{array}$} \\
\hline $\begin{array}{l}\text { Ex- smokers } \\
\text { COPD patients } \\
\text { not on ICS }\end{array}$ & 10 & & 256.08 & 14.55 & & & 4.92 & 1.02 & \\
\hline
\end{tabular}

This table shows that serum levels of both SP-D and CRP were significantly lower among ex smokers COPD patients on ICS compared to ex smokers COPD patients not on ICS. 


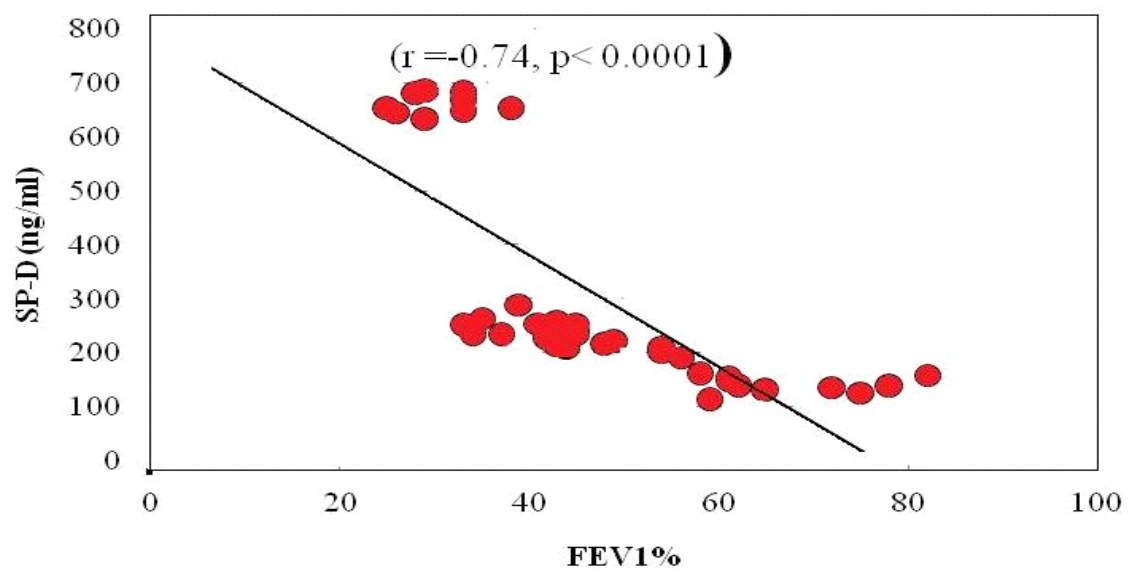

Figure (1): Scatter plot showing the negative correlation between SP-D in serum and FEV1 in COPD patients.

A negative correlation was found between SP-D serum level and FEV1 with PValue $=<0.000$ and $r$-value $=0.74$.

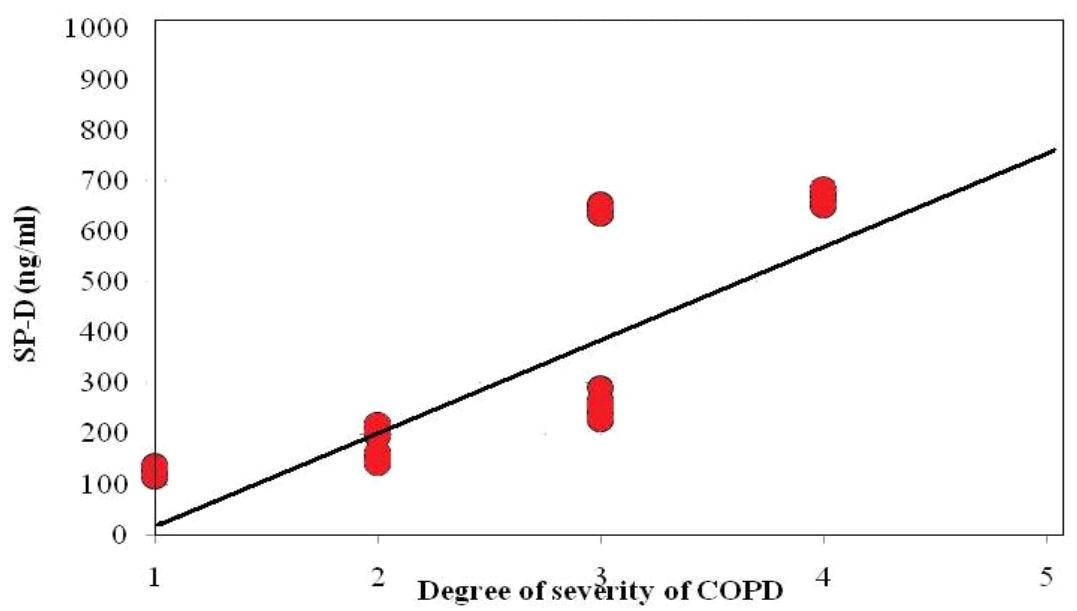

Figure (2): Scatter plot showing the positive correlation between SP-D serum level (ng/ml) and severity of disease

A positive correlation was found between SP-D serum level and severity of disease with $\mathrm{P}-$ Value $=<0.217$ and $\mathrm{r}$-value $=0.335$ 


\section{DISCUSSION}

COPD is a growing epidemic in the world. Despite its huge burden, currently, there are very few COPDspecific drug therapies that can significantly improve health outcomes of COPD patients. There is a pressing need to develop novel drug targets to curb the global epidemic of COPD. SP-D is produced exclusively by type 2 pneumocytes and non-ciliated bronchiolveolar cells. Its presence in the blood is largely determined by the leakiness of the pulmonary epithelium. SP-D has many functional properties including its antiinflammatory and anti-oxidant capacities, and protection against respiratory infections. Collectively, these properties may make it an attractive molecule for further evaluation as a biomarker for epithelial integrity, or a drug target in COPD $^{(1)}$.

Although primarily affecting the lungs, the chronic inflammatory process of COPD does have systemic repercussions. Inflammatory markers, including $\mathrm{C}$ reactive protein (CRP), lipopolysaccharide binding protein, the soluble TNF transmembrane receptor 75 (sTNF-R75), and soluble adhesion molecules are increased in the systemic circulation of patients

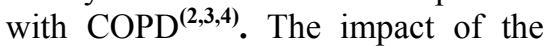
systemic manifestations of COPD on prediction of mortality using a multidimensional index have recently been reported ${ }^{(5)}$. Of these blood-based biomarkers,CRP has shown the greatest promise.

The aim of the present study was the evaluation of the utility of serum
SP-D and CRP as biomarkers for COPD and assessing the effect of inhaled corticosteroids and smoking on their levels.

The results of the current study showed that serum SP-D level was significantly higher in COPD patients when compared to healthy control subjects matching with age and sex (table 2).

By comparing current smokers COPD patients and current smokers control subjects another statistical higher value of SP-D was found with current smokers COPD patients. Once more, a significant higher SP-D serum levels was observed with ex smokers COPD patients when compared with ex smokers control subjects (table 4). These results reveal that COPD is independently associated with increase in SP-D serum levels.

The results of the present work agreed also with Mutti et al. ${ }^{(9)}$ study which included 50 healthy subjects, 30 healthy smokers, 30 asthmatics, and 50 patients with stable COPD. The serum pneumoproteins were immunoassayed and results revealed that serum SP-D concentrations were higher in both smokers and COPD patients than in normal control subjects.

Another study performed by Sims et al. ${ }^{(10)}$ showed that COPD is independently associated with a significant lower level of SP-D in bronchoalveolar lavage (BAL). In the latter study ,BAL was collected from 20 subjects with varying degrees of COPD (8 ex- smokers and 12 current smokers) and 15 asymptomatic healthy control subjects 
(5 non smokers, 3 remote exsmokers, and 7 current smokers).

The possible explanation of all the previous results is that about $75 \%$ of SP-D is found in bronchoalveolar lavage fluid Kishore et al., (11) and its production in BAL increases as certain inflammatory cytokines such as interleukin (IL)-4, IL-6, and IL-13 are potent inducers of its production in the airways Haczku et al., ${ }^{(12)}$ and Kierstein et al., ${ }^{(13)}$ and it is likely that this hydrophilic protein, or its degradation products, leak from the lung as a consequence of increased vascular permeability associated with inflammation. They are then detected within the circulation.

The present study showed that there was a significant difference in mean serum CRP level between COPD patients and healthy subjects as CRP serum concentration was higher in patients with $\operatorname{COPD}$ (table 2).

Yende et al., ${ }^{(14)}$ also reported a higher level of serum CRP in cases with an obstructive pattern in their spirometry $(3.5 \mathrm{mg} / \mathrm{L})$ in comparison to normal population $(2.5 \mathrm{mg} / \mathrm{L})$ $(\mathrm{p}<0.0001)$.

In a study conducted by Broekhuizen et al., ${ }^{(15)}$ stable COPD patients had increased levels of inflammatory markers like CRP $(\mathrm{p}=0.03)$.

Pinto-Plata et al. ${ }^{(16)}$ showed that there was a significant higher level of CRP in COPD patients $(5.03 \pm 1.51$ $\mathrm{mg} / \mathrm{L})$ rather than smoking $(2.02 \pm 1.04$ $\mathrm{mg} / \mathrm{L})$ and non smoking control groups $(2.24 \pm 1.04 \mathrm{mg} / \mathrm{L})(\mathrm{P}<0.001)$.

CRP increases in COPD patients may be due to the inflammatory process itself or related factors such as ischaemic heart disease or smoking ${ }^{(17)}$. In our study IHD patients were excluded and COPD effect on CRP was evaluated as independent factor, so our results further supports the concept that the increase in the CRP level in patients with severe COPD cannot be attributed only to concomitant IHD. As suggested by others, ${ }^{(18)}$ it is possible that the persistent systemic inflammation in patients with COPD may contribute to the pathogenesis of atherosclerosis and cardiovascular disease and explain a high risk of cardiovascular mortality in patients with mild and moderate COPD.

As regards the effect of smoking on the SP-D, in the present study we found that current smokers COPD patients showed significant higher SP-D serum levels compared to ex- smokers COPD patients (table5). Also, there was a statistical significant difference in serum SP-D between current smokers control subjects and ex- smokers control subjects where a higher SP-D level is noticed with current smokers control subjects (table4). On the other hand, no statistical difference was found between ex- smokers control subjects and non smokers control subjects (table3). Also serum level of SP-D $(\mathrm{ng} / \mathrm{ml})$ was significantly higher in current smokers COPD patients not receiving ICS than those Ex-smokers COPD patients not receiving ICS(table6), and also serum level of SP-D $(\mathrm{ng} / \mathrm{ml})$ is significantly higher in current smokers COPD patients receiving ICS than those Ex-smokers COPD patients receiving ICS (table 7).

These results reveal that current smoking status is independently 
associated with significant higher serum SP-D.

The same results were also reported by Mutti et al. ${ }^{(9)}$ in his previously mentioned study found the same positive correlation between current smoking status and serum SPD.

Fernandez-Real et al. ${ }^{\left({ }^{(1)}\right)}$ in his trial to investigate the role of SP-D as a potentially novel risk factor for glucose intolerance and insulin resistance, reported that smokers with normal glucose tolerance showed significantly higher serum SP-D concentration than non smokers.

By measuring SP-D level in bronchoalveolar lavage, Sims et al. ${ }^{(\mathbf{1 0})}$ found that SP-D concentrations were lower in current smoker patients than in ex- and non smoker patients.

Thus, smoking is associated with elevation in serum level of SP-D. Several mechanisms may explain this and among them are: (1) smoking may reduce the production of SP-D by type 2 pneumocytes; or (2) smoking may increase the alveolar-capillary permeability causing SP-D to leak from the lung compartments into the systemic circulation. To test the first mechanism, Hirama et al. ${ }^{(\mathbf{2 0 )}}$ exposed 8-week old $\mathrm{B} 6 \mathrm{C} 3 \mathrm{~F} 1$ mice to daily cigarette smoke (2 cigarettes per day) for 6 months and compared SP-D expression in the lungs of mice exposed to cigarette smoke with the control. The mice exposed to cigarette smoke developed mild emphysema and airway inflammation characterized by increased expression of metalloproteinase (MMP)-9, 12, tumor necrosis factor (TNF)- $\alpha$, and granulocyte macrophage-colony stimulating factor (GM-CSF) in the lungs. They also found increased expression of SP-D in the lungs at both the mRNA and protein level.These data indicate that cigarette smoke up-regulates SP-D expression in the lungs.

There is a large body of evidence indicating that smoking perturbs the integrity of the alveolar capillary interface, leading to increased diffusion of hydrophilic solutes across this barrier Mason et al. ${ }^{\text {(21) }}$

In our study, no difference was observed in the mean CRP level between control smokers and non smokers(table3), Similarly, there was no difference among the patients with COPD who were current smokers and those who were ex smokers(table5). These findings may be due to the absence of an inflammatory response in the smokers, or persistent inflammation in COPD patients even after smoking cessation as seen in human lung samples. The observation that CRP levels did not differ between smoker and non-smoker controls, and between smoker and ex-smoker patients with COPD, also suggests that the increase in CRP levels may represent a phenotype of CRP responders. Little is known about the reason why some persons exposed to cigarette smoke develop clinically important COPD whereas others do not. We speculate that there may be individuals with an "inherited" inflammatory genetic profile .If they are "exposed" to environmental factors (such as smoking or pollution), they have a higher risk of developing COPD.

Concerning the effect of inhaled steroid on SP-D level in serum, a significant difference was found 
between patients receiving inhaled steroid when compared to those receiving bronchodilator only. Serum level of SP-D was significantly lower in current smokers COPD patients receiving ICS than those current smokers COPD patients not receiving ICS(table7).Also serum level of SP-D) was significantly lower in ex-smokers COPD patients receiving ICS than those ex-smokers COPD patients not receiving ICS(table8), suggesting that SP-D may be a biomarker for response to steroid therapy .

A biomarker that reflects the intrapulmonary inflammation of COPD should respond to the administration of a potent antiinflammatory agent. This is what Sin et al. ${ }^{(5)}$ succeeded in demonstrating by examining 289 patients with COPD in a randomized controlled trial, as they found that serum SP-D levels increased during the 4 weeks when inhaled corticosteroids and long-acting $\beta_{2^{-}}$ agonists were withdrawn. In contrast, 4 weeks of treatment with either fluticasone or fluticasone/salmeterol was associated with reduced serum SP-D, indicating that an inhaled corticosteroid in conjunction with a long-acting $\beta_{2^{-}}$ agonist can decrease circulating levels of SP-D.

The changes observed in serum SP-D with withdrawal and institution of therapy could be due to (1) changes in SP-D leakage from the lungs into the circulation, (2) changes in extrapulmonary SP-D production, or (3) changes in SP-D clearance from the circulation. Although none of these can be totally excluded, the first hypothesis seems the most likely as SP-D is primarily produced in the lungs, corticosteroids in this trial were delivered in lung, and other lung pathologies also are associated with elevated serum SP-D Hartl and Griese, ${ }^{(6)}$ and Sorensen et al. ${ }^{(22)}$.

Corticosteroids have been shown to induce expression of SP-D in the fetal lung tissue of both rats and humans (Dulkerian et al. ${ }^{(23)}$ and Wang et al. ${ }^{\text {(24). }}$.

The study performed by Sims et al. ${ }^{\text {(10) }}$ showed that inhaled corticosteroid use is associated with higher levels of SP-D in the lung. Also their study investigated adult type II alveolar epithelial cells isolated from rat lungs and found that similarly to fetal cells, SP-D synthesis depended on constitutive presence of dexamethasone. Given that there are several high potency inhaled steroids widely used to treat COPD and that these steroids are deposited directly on the epithelium, the site of SP-D production. So Sims et al. $^{(10)}$ suspected that these medications may have effects on local SP-D gene expression. Given the high level of evolutional conservation of the SP-D gene promoter sequence between rats and humans, they speculate that inhaled corticosteroids induce expression of SP-D in the adult human lung. Further, this mechanism may enhance the anti-inflammatory effects of inhaled corticosteroids in COPD.

The CRP level in patients with COPD was lower in ICS users than in non users. These results are in agreement with Sin et al. ${ }^{(5)}$ study in which they showed that withdrawal of ICS from patients with mild and moderate disease was associated with a $71 \%$ increase in the baseline CRP 
level. It would be interesting to study larger groups of patients with COPD treated with ICS or withdrawn from ICS to determine if the changes in the number of COPD exacerbations and quality of life observed in those studies correlate with changes in the CRP level.

The current study showed a significant increase in SP-D serum levels with increasing severity of disease (as assessed by GOLD score) (figure 2).

Similarly, Sin et al. ${ }^{(\mathbf{1 7 )}}$ reported a significant inverse relationship between FEV1 and SP-D level in serum among 23 patients of variable degrees of obstruction.

Krane and Griese ${ }^{(18)}$ reported also the previous correlation but among patients with cystic fibrosis. 22 patients with CF and 19 control patients without a pulmonary disease were enrolled in their study and results revealed a clear negative correlation between SP-D concentration and overall lung function, i.e. forced expiratory volume in one second.

Lomas et al. $^{(8)}$ reported no significant correlation between severity of COPD (as assessed by GOLD score) and serum SP-D.

Supporting the results of the previous study Sims et al. ${ }^{(10)}$ though reported that subjects with very severe COPD (GOLD 4) had lower levels of SP-D in BAL compared with subjects with GOLD stage 2 or 3 diseases, yet it showed that this difference was not statistically significant. Clearly, further studies with larger numbers of subjects are required to ultimately prove or disprove this correlation.
Regarding the severity of disease based on GOLD criteria, the mean serum CRP level was increased in severe cases but this correlation was not statistically significant.

Pinto-Plata et al. ${ }^{(16)}$ showed that there was no significant difference between the severity of disease and serum CRP level but de Torees and co-workers $^{(25)}$ indicated that serum CRP level was significantly increased by aggravation of disease.Although we expect the inflammatory process to be worse and the inflammatory markers to be increased by increasing the severity of disease,more studies are required in this regard.

In conclusion, we have confirmed that serum CRP and SP-D levels are significantly raised in patients with COPD and this increase is not related to smoking.Also our study revealed that both markers are lowered by inhaled steroid which empower the sensitivity of both markers in diagnosis of COPD and following the response of the patients to steroid therapy.On the other hand, SP-D levels increased significantly with increasing severity of COPD disease, while CRP did not. This reflects that only SP-D but not CRP could be used as a serum marker to track disease progression in COPD patients.

\section{REFERENCES}

1. Barnes PJ, Chowdhury B, Kharitonov SA, Magnussen $H$, Page CP, Postma D, Saetta M. (2006) Pulmonary biomarkers in chronic obstructive pulmonary disease. Am J Biomarkers and surrogate endpoints: preferred definitions and conceptual 
framework. Clin Pharmacol Ther Respir Crit Care Med;174:6-14.

2. Cazzola M, MacNee W, Martinez FJ, Rabe KF, Franciosi LG, Barnes PJ, Brusasco V, Burge PS, Calverly PMA, Celli BR, et al.( 2008) Outcomes for COPD pharmacological trials: from lung function to biomarkers. Eur Respir J;31:416-468.

3. Biomarkers Definitions Working Group (2001) Biomarkers and surrogate endpoints: preferred definitions and conceptual framework. Clin Pharmacol Ther;69:89-95.

4. Zhu G, Warren L, Aponte J, Gulsvik A, Bakke P, Anderson WH, Lomas DA, Silverman EK, Pillai SG.( 2007) The SERPINE2 gene is associated with chronic obstructive pulmonary disease in two large populations. Am J Respir Crit Care Med ;176:167-173.

5. Sin DD,Man SFP,MarciniukDD, FordG, FitzGeraldM,Wong E,York E, Mainra RR, Ramesh W, Malenka LS, et al.; ( 2008) The effects of fluticasone with or without salmeterol on systemic biomarkers of inflammation in chronic obstructive pulmonary disease. Am J Respir Crit Care Med ;177: 1207-1214.

6. Hartl D, Griese M.( 2006) Surfactant protein D in human lung diseases. Eur J Clin Invest;36:423-435.

7. Rabe KF, Hurd S, Anzueto A, Barnes PJ, Buist SA, Calverley P, Fukuchi Y, Jenkins C, Rodriguez-Roisin $R$, van Weel
C, et al.( 2007) Global strategy for the diagnosis, management, and prevention of chronic obstructive pulmonary disease: GOLD executive summary. Am J Respir Crit Care Med ;176:532555.

8. Lomas D.A. Silverman E.K., Edwards L.D., Locantore N.W., Miller B.E, Horstman D.H., Tal-Singer R. (2009) Serum surfactant protein $\mathrm{D}$ is steroid sensitive and associated with exacerbations of COPD Eur. Respir. J. 34(1):95-102.

9. Mutti A., Corradi M., Goldoni M., Vettori M.V., Bernard A., Apostoli P. (2006) Exhaled metallic elements and serum pneumoproteins in asymptomatic smokers and patients with COPD or asthma. Chest. 129(5): 1288 1297.

10. Sims M.W, Tal-Singer R.M, Kierstein S., Musani A.I., Beers M.F., Panettieri Jr. R.A., Haczku A. (2008) chronic obstructive pulmonary disease and inhaled steroids alter surfactant protein D (SP-D) levels: a cross-sectional study. Respir. Res. 9:13.

11. Kishore U., Greenhough T.J., Waters P., Shrive A.K., Ghai R., Kamran M.F., Bernal A.L., Reid K.B., Madan T., Chakraborty T. (2006) Surfactant proteins SP-A and SP$\mathrm{D}$ : structure, function and receptors. Mol. Immunol.43(9): 1293-1315.

12. Haczku A., Cao Y., Vass G., Kierstein S., Nath P., AtochinaVasserman, E.N. (2006) IL-4 and IL-13 form a negative 
feedback circuit with surfactant protein-D in the allergic airway response. J.Immunol. 176(6): 3557- 3565.

13. 13.Kierstein S., Poulain F.R., Cao Y., Grous M., Mathias R., Kierstein G., Beers M.F., Salmon M., Panettieri Jr. R.A., Haczku A. (2006) Susceptibility to ozone-induced airway inflammation is associated with decreased levels of surfactant protein D. Respiratory Research. 7:85.

14. Yende S, Waterer GW, Tolley EA, Newman AB, Bauer DC, Taaffe DR, et al. (2006) Inflammatory markers are associated with ventilatory limitation and muscle dysfunction in obstructive lung disease in well functioning elderly subjects. Thorax; 61 (1): 10- 6 .

15. Broekhuizen $R$, Wouters EF, Creutzberg EC, Schols AM. (2006) Raised CRP levels mark metabolic and functional impairment in advanced COPD. Thorax; 61 (1): 17- 22.

16. Pinto-Plata VM, Mullerova $\mathrm{H}$, Toso JF, Feudjo-Tepie M, Soriano JB, Vessey RS, et al.(2006) C-reactive protein in patients Soriano JB, Vessey RS, et al. C-reactive protein in patients with COPD, control smokers and non-smokers. Thorax; 61 (1): 23- 8.

17. Sin D.D., Leung R., Gan W.Q., Man S.P. (2007) Circulating surfactant protein D as a potential lung-specific biomarker of health outcomes in COPD: a pilot study. B.M.C. Pulm. Med. 7:13.
18. Krane M., Griese M. (2003) Surfactant protein D in serum from patients with allergic bronchopulmonary aspergillosis. Eur. Respir. J. 22(4): 592 -595

19. Fernandez-Real J.M., Melania M., Berta C., Patricia B., Arantza C., Elías D., Javier S., Geltrude M., Wifredo R.V., Roser C. (2010) Surfactant Protein D, a Marker of Lung Innate Immunity, Is Positively Associated With Insulin Sensitivity. Diabetes Care. 33(4): 847-853.

20. Hirama N., Shibata Y., Otake K., Machiya J., Wada T., Inoue S. (2007) Increased surfactant protein-D and foamy macrophages in smoking-induced mouse emphysema. Respirology 12(2): 191201.

21. Mason G.R., Peters A.M., Bagdades E., Myers M.J., Snook D., Hughes J.M. (2001) Evaluation of pulmonary alveolar epithelial integrity by the detection of restriction to diffusion of hydrophilic solutes of different molecular sizes. Clin. Sci. (Lond) 100(3): 231- 236.

22. Sorensen G.L., Husby S., Holmskov U. (2007) Surfactant protein A and surfactant protein $\mathrm{D}$ variation in pulmonary disease. Immunobiology.212:381-386.

23. Dulkerian S.J., Gonzales L.W., Ning Y., Ballard P.L. (1996) Regulation of surfactant protein $\mathrm{D}$ in human fetal lung. Am. J. Respir. Cell Mol. Biol. 15(6):781-786.

24. Wang J.Y., Yeh T.F., Lin Y.C., Miyamura K., Holmskov U., Reid K.B. (1996) Measurement 
of pulmonary status and surfactant protein levels during dexamethasone treatment of neonatal respiratory distress syndrome. Thorax. 51(9):907913.

25. de Torres JP, Cordoba-Lanus E, Lopez-Aguilar C, Muros de
Fuentes M, Montejo de Garcini A, Aguirre-Jaime A, et al. (2006) Creactive protein levels and clinically important predictive outcomes in stable COPD patients. Eur Respir J; 27(5): 902- 7. 


\section{البروتين المتفاعل سى وبروتين السيرفاكتتب د كدلالاتين حيويتين فى الدم فى العى مرض السدة الرئوية المزمنة د الاتين}

يعد مرض السدة الرئوية المزمنة أحد الأمر اض التى تزداد خطورتها فى العالم .وبالر غم من فداحة الخسائر

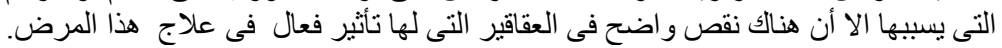

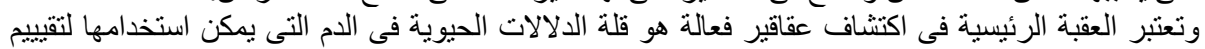
فاعلية تلك العقاقير. ان بروتين السيرفاكتتث)د -(احد البروتينات المستمدة من الرئة ـله دور كبير في الوقاية من امر اض الجهاز

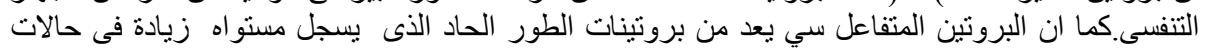

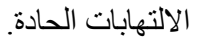

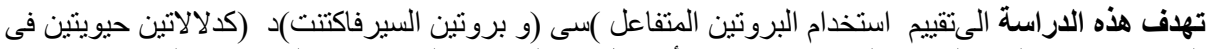

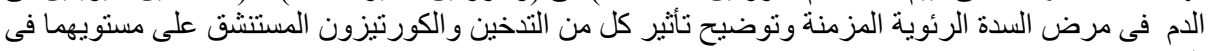

وقد تضمنت الاراسة 70حالة تم تقسيمهم الى مجمو عتين رئيستينين:

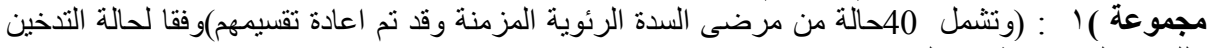

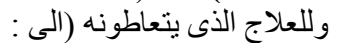

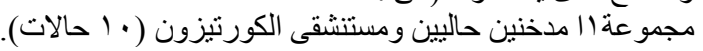

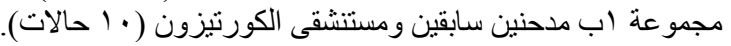

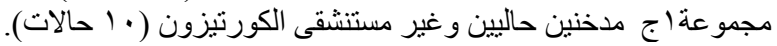
مجموعة اد مدختين سابقين و غير مستنشقى الكورتيزون (· ( حالات).

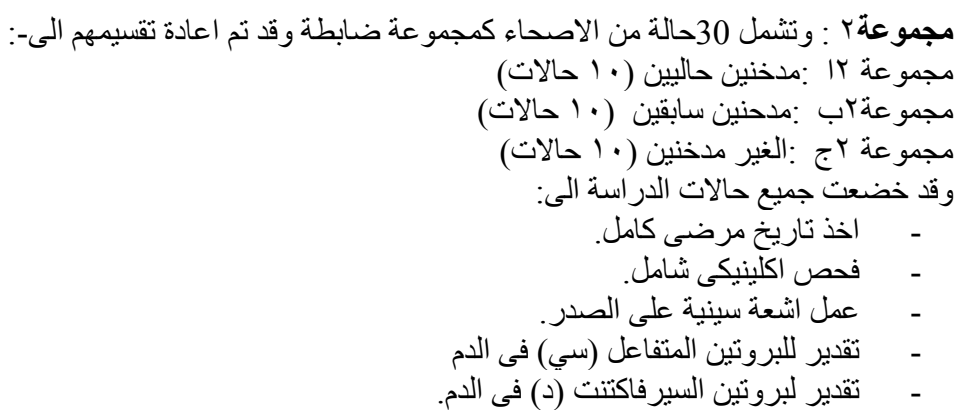

كما خضعت حالات السدة الرئوية المزمنة، بالاضافة الى ذلك، الى عمل وظائف للرئة .

وقد اظهرت النتائج ان كلا من بروتين السيرفاكتتت )د (و البروتين المتفاعل)سى (قد ازدادا ازديادا ذيى دلالة

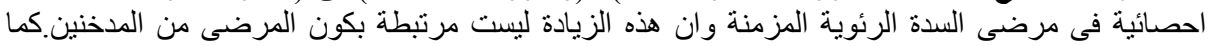

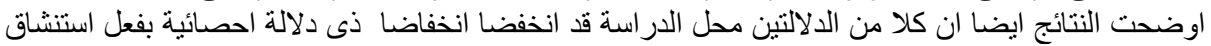

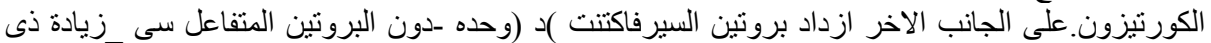

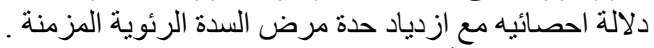

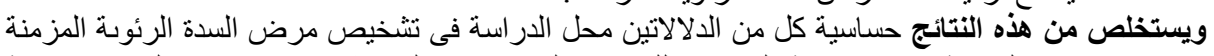

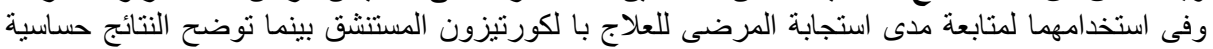

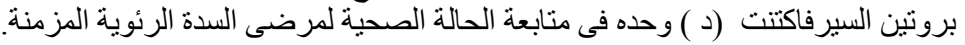

